\title{
Ecological Succession in Agrarian Impacted Site in Parts of Amafor Rainforest in Ngor-Akpala Local Government Area (LGA) of Imo State, Nigeria: Phytodiversity and Species Composition Assessments
}

\author{
F.B.G. Tanee, N.L. Edwin-Wosu and I.A. Nze \\ Department of Plant Science and Biotechnology, Faculty of Biological Sciences, College of Natural and \\ Applied Sciences, University of Port Harcourt, Nigeria
}

\begin{abstract}
Background: Series of ecological demand are causing significant and irreversible loss to forest resource, thus causing their disappearance at alarming rates due to demand for timber and non-timber products and for agricultural lands. In most communities of Ngor-Akpala in Imo State, where mechanized and sustainable system of agriculture is not practiced, shifting cultivation and subsistence farming are the most obvious causes of forest disturbances. Objective: This study elucidates the phytodiversity and composition of an agrarian impacted site in parts of Amafor forest in Ngor-Akpala, Imo State. Methodology: A total of five quadrate sampling plots of $20 \times 50 \mathrm{~m}$ each were systematically sampled and phytosociological data were collected in both the impacted and unimpacted sites. Results: The impacted site had a total representative of 39 species under 17 families recorded in mosaic heterogeneity with herbs (77\%) and shrubs (58\%) as the most dominant life form of plant species. Phytosociological results showed that among the 39 representative species, Spillanthes filicaulis and Ipomoea involucrata recorded the highest frequency of $(100=5.81 \%)$ occurrence. Andropogon tectorum (giant bluestem) had the highest density value of $11.2=18.01 \%$, highest abundance value of $18.7=14.70 \%$ and highest Importance Value Index (IVI) of $36.20 \%$, respectively. In distribution pattern 20 species (51.28\%) had random distribution, $5(12.82 \%)$ species in regular and $14(35.90 \%)$ species in contiguous distribution pattern. The unimpacted site had 19 species under 14 families in climax vegetation structure of six species as herbs, 11 as shrubs and 2 as trees. Phytosociological assessment had four species with the highest frequency of $100=7.69 \%$ with Manniophyton fulvum having the highest density value of $6=10.24 \%$ per species and IVI of $25.11 \%$. Funtumia elastica had the highest abundance of $8=9.30 \%$. The distribution pattern showed 12 species $(63.16 \%)$ in contiguous pattern, 4 species $(21.05 \%)$ in random distribution and 3 species (15. 79\%) regularly distributed. Conclusion: The comparative study on the similarity of the impacted and unimpacted sites shows that both sites are dissimilar with an observed index value of 0.79 higher than the 0.21 value of similarity index.
\end{abstract}

Key words: Phytosociology index, diversity, agrarian practice, ecological succession, distribution pattern

Insight Ecology 4 (1): 35-45, 2015

\section{INTRODUCTION}

The tropical rainforest constitutes the most biological diverse terrestrial ecosystem on earth ${ }^{1}$. Across the world, 25 hot-spots have been identified on the basis of species endemism and degree of threat through habitat $\operatorname{loss}^{2}$. It is the predominant natural forest in Nigeria occupying about $10 \%$ of land mass $^{3}$ which have been extensively degraded and exist in patches. Forest vegetation represents an important natural resource

Corresponding Author: N.L. Edwin-Wosu, Department of Plant Science and Biotechnology, Faculty of Biological Sciences, College of Natural and Applied Sciences, University of Port Harcourt, Nigeria with diverse scientific, technological, cultural and ecological values at the local, state, national and international levels of societal needs. Despite these immense economic and ecological values of forest to $\operatorname{man}^{4}$, noted series of ecological demand incursion by the society to be causing significant and irreversible loss to this unique resource.

These forests are disappearing at alarming rates owing to deforestation for extraction of timber and other forest products and diverse forms of agricultural activities. In most communities of Ngor-Akpala in Imo State, Nigeria, especially where mechanized and sustainable system of agriculture is not practiced, shifting 
cultivation and subsistence farming as the most common operations been practiced are the most obvious causes of forest disturbances. The problem with the chronic form of disturbance is that plants or ecosystem often do not get time to recover adequately because the human on slaught never stops ${ }^{5}$.

Several other biotic and abiotic factors have been noted as agents of species ecological amplitude $e^{6,7,8}$. This concomitantly amount to some degree of ecological succession causing direct changes in plant species abundance in terms of frequency of occurrence and density. Other succession impacts involve changes in species diversity (in terms of richness and evenness), relative density, relative frequency, relative abundance, Importance Value Index (IVI), ratio of abundance to frequency $(\mathrm{A} / \mathrm{F})$ and plant species regeneration and habit.

Diversity provides an observer a feeling of satisfaction in the natural world ${ }^{9}$. Phytodiversity studies in tropical rainforest are important to determine the process or mechanisms that maintain high diversity, species richness, species assemblages and at the same time providing a database about the number and status of the species existing in an area and their conservation ${ }^{10,11}$. An obvious approach to conserve plant biodiversity is to map distributional patterns and look for concentrations of diversity and endemism ${ }^{12}$. Further, management of forest requires understanding of its composition in relation to other forests, the effects of past impacts on the present status and the present relationship of the forest with surrounding land use ${ }^{13}$. Very often ecologists find it necessary to compare different vegetation structure and complex of the same localities and/or different localities. This comparison has usually been done for conservation and management purposes. An objective and quantitative way of comparing vegetation of two different or similar localities is to examine the similarities in species composition and content in line with conservation priorities.

Agriculture has a significant effect on species diversity and amplitude because of its prevalence over landscape. Such effect may include habitat alteration, exotic pest introduction, pollution from pesticides and fertilizer etc. Loss of plant species diversity due to agricultural expansion and plantation establishment is rapidly increasing. Such loss is often attributed to population growth particularly in suburb and in rural community such as Amafor, where such losses may be linked to rural poverty and farmers' ignorance to values and functions of biodiversity and severity of subsistence farming activity involving bush burning. Floristic diversity and phytosociological study of Amafor forest in Ngor-Akpala in Imo State, Nigeria is lacking. Therefore, the present study was undertaken to assess the plant biodiversity and vegetation analysis due to agrarian impact on Amafor forest in Ngor-Akpala LGA of Imo State, Nigeria.

\section{MATERIALS AND METHODS}

Geo-morphological description of the study area/location: Ngor-Akpala local government area among others in Eastern part of Nigeria is located in Imo State. The area is situated between latitude $05^{\circ} 20^{\prime} 0^{\prime \prime} \mathrm{N}$ and $05^{\circ} 25^{\prime} 0{ }^{\prime \prime} \mathrm{N}$ and longitude $007^{\circ} 10^{\prime} 0^{\prime \prime} \mathrm{E}$ and $007^{\circ} 15^{\prime} \mathrm{O}^{\prime \prime} \mathrm{E}$ of the State. The local government area is housing among other autonomous community, the Amafor Community. The study location, Amafor is located north-west of Ngor-Akpala local government area in Imo State. The location is situated between latitude $05^{\circ} 20^{\prime} 0^{\prime \prime} \mathrm{N}$ and $5^{\circ} 25^{\prime} 0^{\prime \prime} \mathrm{N}$ and longitude $007^{\circ} 5^{\prime} 00^{\prime \prime} \mathrm{E}$ and $007^{\circ} 10^{\prime} 0$ "E of its location in Imo State (Fig. 1). The site is being under exploitation of agrarian human influence for domestic firewood logging, charcoal production (carbon credit) and diverse plantations of agricultural produce for both local consumption and marketing.

The study area is characterized by two season, the rainy and dry seasons. The rainy season falls with its peak between June and October, its lowest recorded from November to January with annual rainfall varying from 1500-2544.10 mm. A mean temperature of above $27^{\circ} \mathrm{C}$ with the lowest and highest in the area being 19 and $33^{\circ} \mathrm{C}$ is respectively recorded. Relative humidity is $75-90 \%$ at peak rainfall. The dry season between November and March experiences with peak temperature and humidity between January and March. This favours the luxuriant vegetation growth of the area (en.wikipedia.org/wiki/imo_state).

The area in its edaphic status is underlain by the Benin formation of coastal plain sands. This formation which is of late tertiary age is rather deep, porous, infertile and highly leached. In some areas like Okigwe, impermeable layer of clay occur near the surface while in other areas, the soil consists of lateritic material under a superficial layer of fine grained sand. In Amafor study site the soil is dominantly clay-loamy with its lateritic coloration due to the rainfall weathering and oxidation processes of iron (II) to iron (III) oxide $\left(\mathrm{Fe}^{2+} \rightarrow \mathrm{Fe}^{3+}\right)$ causing colour change. The area is also rich in lead, zinc, coal tar (hydrocarbon formation).

The study area is in the centre of one of the agricultural zones of the State. The vegetation primarily though of climax nature is of typical secondary nature 


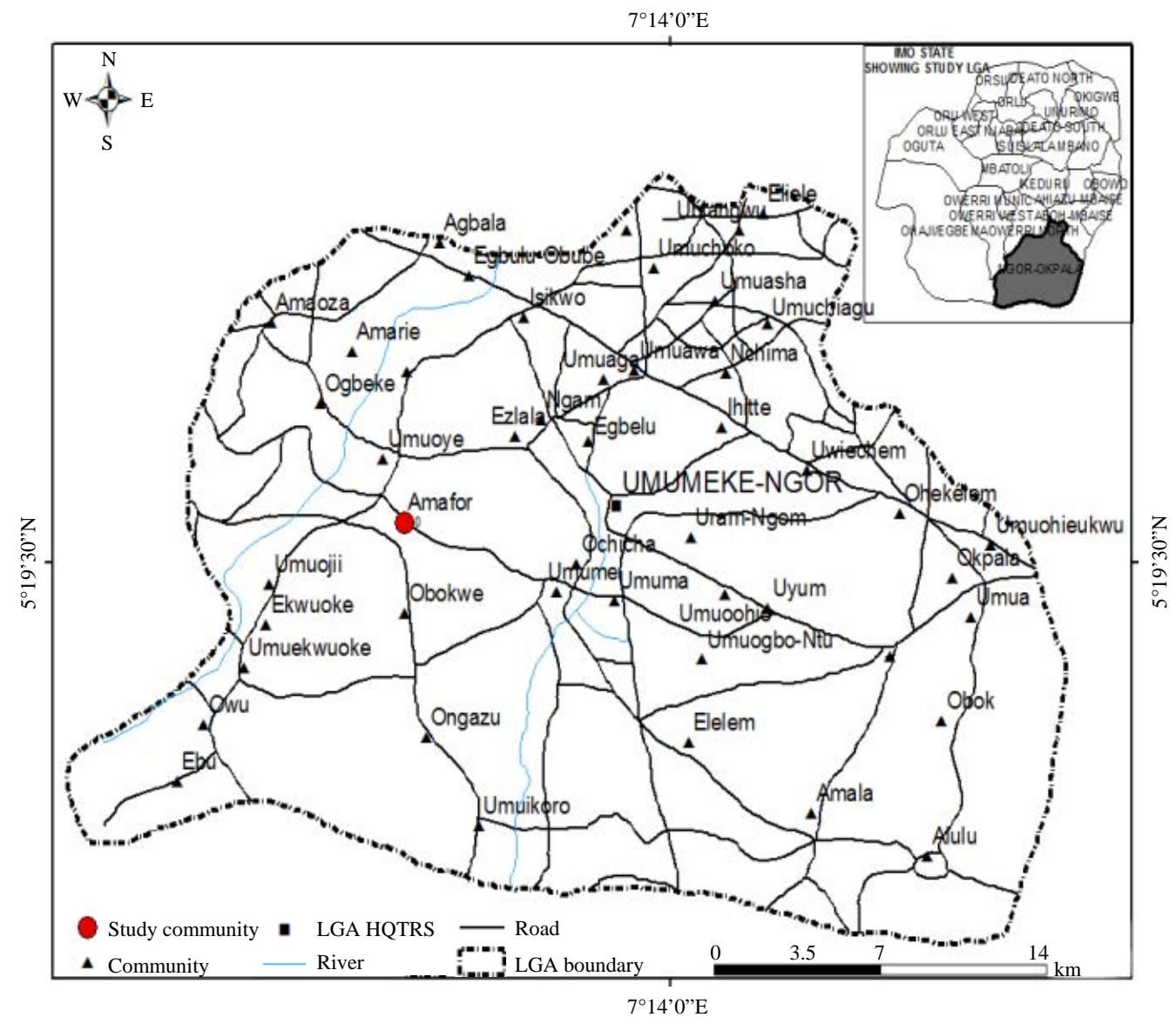

Fig. 1: Map of study area/site

with its prevalent species of ecological succession regenerating from the effect of agrarian activities. The successive vegetation of the area is characterized by prevalent species of shrubs, herbs, climbers, lianers and dominantly members of Poaceae, Asteraceae, Sterculiaceae, Connaraceae, Fabaceae, Convolvulaceae, Tiliaceae, Icacinaceae, Malvaceae, Rubiaceae, Dioscoreaceae, Melastomataceae, Euphorbiaceae, Combretaceae, Polygalaceae, Urticaceae, Polygalaceae, Passifloraceae, Cyperaceae, Apocynaceae, Loganiaceae, Dilleniaceae, Guttiferae and Verbenaceae plant families, typical of secondary succession fallowed bush. The environment has also witnessed some form of human activities such as farming far and near residential areas by the local communities leaving fields of plantations such as Manihot spp. (Euphorbiaceae), Musa spp. (Linn.) (Musaceae); Xanthosoma malfaffa Schott (Araceae) and Coloccasia esculenta (Linn.) Schott (Araceae). Though primarily, in a climax vegetation of various strata the effect of these agrarian activities has consequently left it with some form of irregular vegetation features. This can therefore, be categorized as a low land secondary mosaic forest as described by Hopkin ${ }^{14}$. However, the vegetation is yet described as rainforest vegetation in relation to similar view of vegetation analysis by SAF $^{15}$ and Edwin-Wosu ${ }^{16-19}$.

Vegetation assessment: It was carried out by adopting the simple random sampling based on standard procedures for ecological assessment studies ${ }^{20}$ with specific quadrate direction of $100 \times 50 \mathrm{~m}$ to determine the regeneration status of the site. This was divided into sampling unit to give a total of five quadrate sampling plot of $20 \times 50 \mathrm{~m}$ each and was systematically sampled. All the important representative plant species sampled were identified in the field as far as possible and were properly authenticated using flora such as ${ }^{21-27}$. 
Data analyses: The frequency (F\%) of distribution, abundance (A), density (D), Relative Frequency (RF), Relative Abundance (RA), Relative Density (RD), Importance Value Index (IVI) and abundance-frequency ratio $(\mathrm{A} / \mathrm{F})$ of the representative species of the study site were estimated using the methods of Austin ${ }^{28}$, Kershaw $^{29}$ and Shukla and Chandel ${ }^{30}$ as modified by Bonham ${ }^{31}$. The species diversity and dominance over the study site was estimated using the Shannon and Weiner ${ }^{32}$ index. Vegetation was described in semi-quantitative terms ${ }^{33}$ and in accordance species with a wide frequency of distribution with many stands are described as very abundant $(++++)$. Some species with similarly wide frequency of distribution but with few stands are said to be less frequent, abundant or restricted species $(+++)$. The species with limited geographical distribution and with a few stands are termed scarce or occasional $(++)$ and very scarce or rare $(+)$ species. The species designated $(++)$ and $(+)$ are often seen as being prone to elimination due to their limited extent alone beside any other factors. Relative density, relative abundance and relative frequency were estimated following $\mathrm{Misra}^{34}$ method while the Importance Value Index (IVI) was estimated by the cumulative ecological indices using the Shukla and Chandel ${ }^{30}$ method. The ratio of abundance to frequency $(\mathrm{A} / \mathrm{F})$ for different species was determined for distribution patterns. Thus with the "Thumb of rule" designated as follows: Regular $(<0.03)$, Random $(0.03-0.05)$ and Contiguous $(>0.05)$ distribution as adopted by Curtis and Cottam ${ }^{35}$. The assessment of similarity or dissimilarity for the two sites was carried out using the Sorensen ${ }^{36}$ index.

\section{RESULTS}

The project study location with its situate lying between Lat. $5^{\circ} 20^{\prime} 0^{\prime \prime} \mathrm{N}$ and $5^{\circ} 25^{\prime} 0^{\prime \prime} \mathrm{N}$ and Long. $7^{\circ} 10^{\prime} 0$ ” E and $7^{\circ} 15^{\prime} 0^{\prime \prime} \mathrm{E}$ of the study area is part of Amafor tropical rainforest impacted by the unsustainable and pristine agricultural activities practiced by the people of Amafor community in Ngor-Akpalla Local Government Area of Imo State. The area under investigation is characterized by secondary vegetation complex, mosaic in nature with a heterogeneous spatial continuum arrangement, due to the biotic influence of ecological incursion. Agronomic practices such as subsistence crop farming and charcoal production carbon credit activities were been carried out, with concomitant aggressive logging and loss of forest woody species of homogenous climax nature. Despite such ecological incursion with resultant primary succession of the impacted site, the study area of assessment involving the impacted and the unimpacted control sites (Table 1-4), respectively were observed with plant species of various strata and categories belonging to different families with representative species of the various sites recorded based on the phyto-sociological indices of ecological assessment.

In the present study the vegetation complex of the impacted site recorded a total representative of 39 species under 17 families with mosaic heterogeneity (Table 1). Four families (Poaceae, Asteraceae, Fabaceae and Rubiaceae) were prevalently dominant, with two (Asteraceae and Rubiaceae) in abundance while Poaceae and Fabaceae were found to be very abundant. Under such ecological assessment, herbs and shrubs were the most dominant plant species in the study areas. They were represented by 30 and 9 species, respectively distributed among the 17 families. Poaceae was the most diverse with 10 species, Fabaceae 7 species, Asteraceae and Rubiaceae, has three species each. Similar ecological assessment with the phytosociological index application on the species prevalence of the study area (Table 2) shows that among the 39 representative species two species (Spillanthes filicaulis and Ipomoea involucrata-morning glory) recorded the highest frequency of $(100=5.81 \%)$ occurrence while the density per species had indicated Andropogon tectorum (giant bluestem) with the highest density value of $11.2=18.01 \%$ and highest abundance value of $18.7=14.70 \%$.

The cumulative status of species prevalence among the representatives in the study site has shown 12 species with maximum value index range of $10.49-36.20 \%$ and with the highest Importance Value Index (IVI) of $36.20 \%$ recorded by $A$. tectorum. The ratio of abundance to frequency in distribution pattern of the species in the site shows that greater proportion of the species $(20=51.28 \%)$ was randomly distributed in spatial continuum, indicating a greater impact and disturbance in the habitat while $5(12.82 \%)$ species were regularly and $14(35.90 \%)$ species were contiguous in distribution pattern.

In a similar assessment of the unimpacted control site a total representative of 19 species under 14 families were recorded (Table 3) in a homogenous climax vegetation structure. One family (Euphorbiaceae) was prevalently dominant and very abundant. Under such study, the life form of the species showed that six species exist as herbs in transition, eleven species as shrubs and two species as trees in which Euphorbiaceae recorded highest diversity with four species among the families of the life form habitat. 
Table 1: Survey estimate of representative species around the Agrarian impacted Amafor forest in Ngor-Akpala local government area of Imo state

\begin{tabular}{|c|c|c|c|c|c|}
\hline Species & $\mathrm{F}(\%)$ & Family & Habit & Common name & Remark \\
\hline Axonopus flexousus (Peter) Troupin & 40 & Poaceae & Herb & & ++ \\
\hline Andropogon tectorum Schum and Thonn. & 60 & Poaceae & Herb & Giant bluestem & +++ \\
\hline Eragrostis ciliaris (Linn.) R.Br. & 40 & Poaceae & Herb & Love grass & ++ \\
\hline Spillanthes filicaulis (Schum and Thonn.) C.D. Adams. & 100 & Asteraceae & Herb & & +++++ \\
\hline Scleria naumanniana Boeck & 20 & Cyperaceae & Herb & Bush knife & + \\
\hline Melochia melissifolia Benth. & 20 & Sterluliaceae & Herb & & + \\
\hline Paspalum conjugatum Berg. & 40 & Poaceae & Herb & Sour grass & ++ \\
\hline Panicum maximum Jacq. & 40 & Poaceae & Shrub & Guinea grass & ++ \\
\hline Cnestis ferruginea DC. & 40 & Connaraceae & Shrub & & ++ \\
\hline Perotis indica (Linn.) O. Ktze & 80 & Poaceae & Herb & & ++++ \\
\hline Senna occidentalis (Linn.) Link. & 20 & Fabaceae-ceasal & Shrub & & + \\
\hline Chamaecrista mimosoides (Linn.) Greene & 40 & Fabaceae-mimo & Shrub & & ++ \\
\hline Ipomoea involucrate P. Beauv. & 100 & Convolvulaceae & Herb & Morning glory & +++++ \\
\hline Truimfetta cordifolia A. Rich. & 60 & Tiliaceae & Herb & & +++ \\
\hline Icacina trichantha Olive. & 80 & Icacinaceae & Herb & & ++++ \\
\hline Urena lobata Linn. & 40 & Malvaceae & Shrub & Hibiscus bur & ++ \\
\hline Calopogonium mucunoides Desv. & 60 & Fabaceae & Herb & & +++ \\
\hline Panicum laxum Sw. & 60 & Poaceae & Herb & & +++ \\
\hline Oldenlandia affinis & 20 & Rubiaceae & Herb & & + \\
\hline Dioscorea smilacifolia & 20 & Dioscoreaceae & Herb & & + \\
\hline Andropogon gayanus Kunth. & 40 & Poaceae & Herb & Gamba grass & ++ \\
\hline Baphia nitida Lodd. & 40 & Fabaceae & Shrub & & ++ \\
\hline Aspilla bussei O. Hoffm. & 80 & Asteraceae & Herb & White flower Aspilla & ++++ \\
\hline Dioda sermentosa Sw. & 60 & Rubiaceae & Herb & & +++ \\
\hline Heterotis rotundifolia (Sm.) Jac. & 80 & Melastomataceae & Herb & Chick weed & ++++ \\
\hline Laportea ovalifolium (Schum). Chew & 40 & Urticaceae & Herb & Tropical stinging nettle & ++ \\
\hline Digitaria horizontalis Willd. & 40 & Poaceae & Herb & Digit grass & ++ \\
\hline Alcalypha ciliata Forssk & 40 & Euphorbiaceae & Herb & & ++ \\
\hline Chromolaena odorata (Linn.) RM King and Robinson & 20 & Asteraceae & Herb & Siam weed & + \\
\hline Desmodium scolporius (Sw.) Desv. & 40 & Fabaceae & Herb & & ++ \\
\hline Lonchorcarpus cyanescens (Schum and Thonn.) Benth. & 60 & Fabaceae & Shrub & & +++ \\
\hline Nauclea diderrechii (De Wild and Th. Dur.) Merrill & 20 & Rubiaceae & Shrub & & + \\
\hline Alchornea cordifolia & 40 & Euphorbiaceae & Shrub & Christmas bush & ++ \\
\hline Oplimenus baumanni (Retz) P. Beauv. & 20 & Poaceae & Herb & Grass & + \\
\hline Combretum zenkeri Engl. and Diels & 20 & Combretaceae & Herb & & + \\
\hline Carpolobia lutea G.Don & 20 & Polygalaceae & Shrub & Poor man's candle & + \\
\hline Desmodium ramosissimium G.Don & 20 & Fabaceae & Herb & & + \\
\hline Clerodendrum splendens G.Don. & 40 & Verbenaceae & Herb & & ++ \\
\hline Triumfetta eriophlebia Hook. f. & 20 & Tiliaceae & Herb & & + \\
\hline
\end{tabular}

$\frac{1}{+(1-25) \text { Very scarce, }++(26-59) \text { Scarce, }+++(60-79) \text { Abundant, }++++>(80-\alpha) \text { Very abundant, NA: Not available, F (\%): Percentage }}$ frequency

Result of phytosociological assessment (Table 4) indicated four species (H. rotundifolia-cheekweed, Anthonotha macrophylla-West African rosewood, Stachytarpheta jamaicensis-Brazilian tea and Harrungana madagascariensis-dragon's blood) with the highest frequency $(\mathrm{F} \%)$ of $100=7.69 \%$ occurrence among the representative while six species had maximum density value range of $4-6=6.83-10.24 \%$ with cheek weed and Manniorphyton fulvum recording the highest value of $6=10.24 \%$ species $^{-1}$. In similar study eleven species had maximum abundance of 4-8 $=4.65-9.30 \%$ with Funtumia elastica recording the highest value of $8=9.30 \%$ while 16 species recorded a maximum cumulative status of prevalence with a range value of $10.46-25.11 \%$ in which $M$. fulvum had the highest importance value index (25.11\%). The distribution pattern recorded some level of homogeneity with majority of species in contiguous pattern of spatial continuum of $12(63.16 \%)$ while four $(21.05 \%)$ species were randomly distributed and three $(15.79 \%)$ regularly distributed.

Generally, in all bounding coordinates at the study sites, there was increase in herbaceous status in terms of species life forms in the impacted site with $77 \%$ of the representative species as herbs and increase in shrubby life form with $58 \%$ of the representative as shrubs. The herbaceous increase in the impacted site is an indication of a primary regeneration succession which seems to be in progressive transition through time toward shrubby and tree life forms if protected to conserve the 
Table 2: Quantitative list of representative species around the Agrarian impacted Amafor forest in Ngor-Akpala local government area of Imo state

\begin{tabular}{|c|c|c|c|c|c|c|c|c|}
\hline Species & $\mathrm{F}(\%)$ & $\mathrm{D}$ & $\mathrm{A}$ & RF (\%) & $\mathrm{RD}(\%)$ & $\mathrm{RA}(\%)$ & IVI & $\mathrm{A} / \mathrm{F}$ \\
\hline Axonopus flexousus (Peter) Troupin & 40 & 2.6 & 6.5 & 2.33 & 4.18 & 5.11 & 11.62 & 0.16 \\
\hline Andropogon tectorum Schum and Thonn. & 60 & 11.2 & 18.7 & 3.49 & 18.01 & 14.70 & 36.20 & 0.31 \\
\hline Eragrostis ciliaris (Linn.) R.Br. & 40 & 1.8 & 4.5 & 2.33 & 2.89 & 3.54 & 8.76 & 0.11 \\
\hline Spillanthes filicaulis (Schum and Thonn.) C.D. Adams. & 100 & 3.2 & 3.2 & 5.81 & 5.14 & 2.52 & 13.47 & 0.03 \\
\hline Scleria naumanniana Boeck & 20 & 0.2 & 1.0 & 1.16 & 0.32 & 0.79 & 2.27 & 0.05 \\
\hline Melochia melissifolia Benth. & 20 & 0.2 & 1.0 & 1.16 & 0.32 & 0.79 & 2.27 & 0.05 \\
\hline Paspalum conjugatum Berg. & 40 & 1.4 & 3.5 & 2.33 & 2.25 & 2.75 & 7.33 & 0.09 \\
\hline Panicum maximum Jacq. & 40 & 0.4 & 1.0 & 2.33 & 0.64 & 0.79 & 3.76 & 0.03 \\
\hline Cnestis ferruginea DC. & 40 & 0.4 & 1.0 & 2.33 & 0.64 & 0.79 & 3.76 & 0.03 \\
\hline Perotis indica (Linn.) O. Ktze & 80 & 3.6 & 4.5 & 4.65 & 5.79 & 3.54 & 13.98 & 0.06 \\
\hline Senna occidentalis (Linn.) Link. & 20 & 0.2 & 1.0 & 1.16 & 0.32 & 0.79 & 2.27 & 0.05 \\
\hline Chamaecrista mimosoides (Linn.) Greene & 40 & 0.4 & 1.0 & 2.33 & 0.64 & 0.79 & 3.76 & 0.03 \\
\hline Ipomoea involucrate P. Beauv. & 100 & 2.4 & 2.4 & 5.81 & 3.86 & 1.89 & 11.56 & 0.02 \\
\hline Truimfetta cordifolia A. Rich. & 60 & 0.6 & 1.0 & 3.49 & 0.96 & 0.79 & 5.24 & 0.02 \\
\hline Icacina trichantha Olive & 80 & 1.4 & 1.8 & 4.65 & 2.25 & 1.42 & 8.32 & 0.02 \\
\hline Urena lobata Linn. & 40 & 0.2 & 0.5 & 2.33 & 0.32 & 0.39 & 3.04 & 0.01 \\
\hline Calopogonium mucunoides Desv. & 60 & 1.6 & 2.7 & 3.49 & 2.57 & 2.12 & 8.18 & 0.05 \\
\hline Panicum laxum Sw. & 60 & 5.4 & 9.0 & 3.49 & 8.68 & 7.08 & 19.25 & 0.15 \\
\hline Oldenlandia affinis & 20 & 0.2 & 1.0 & 1.16 & 0.32 & 0.79 & 2.27 & 0.05 \\
\hline Dioscorea smilacifolia & 20 & 0.2 & 1.0 & 1.16 & 0.32 & 0.79 & 2.27 & 0.05 \\
\hline Andropogon gayanus Kunth. & 40 & 3.0 & 7.5 & 2.33 & 4.82 & 5.90 & 13.05 & 0.19 \\
\hline Baphia nitida Lodd. & 40 & 0.4 & 1.0 & 2.33 & 0.64 & 0.79 & 3.76 & 0.03 \\
\hline Aspilla bussei O. Hoffm. & 80 & 4.2 & 5.3 & 4.65 & 6.75 & 4.17 & 15.57 & 0.07 \\
\hline Dioda sermentosa $\mathrm{Sw}$ & 60 & 1.0 & 1.6 & 3.49 & 1.61 & 1.26 & 6.36 & 0.03 \\
\hline Heterotis rotundifolia (Sm.) Jac. & 80 & 3.2 & 4.0 & 4.65 & 5.14 & 3.14 & 12.93 & 0.05 \\
\hline Laportea ovalifolium (Schum). Chew & 40 & 0.4 & 1.0 & 2.33 & 0.64 & 0.79 & 3.76 & 0.03 \\
\hline Digitaria horizontalis Willd. & 40 & 2.0 & 10.0 & 2.33 & 3.22 & 7.86 & 13.41 & 0.25 \\
\hline Alcalypha ciliata Forssk & 40 & 0.2 & 0.5 & 2.33 & 0.32 & 0.39 & 3.04 & 0.01 \\
\hline Chromolaena odorata (Linn.) RM King and Robinson. & 20 & 0.4 & 1.0 & 1.16 & 0.64 & 0.79 & 2.59 & 0.05 \\
\hline Desmodium scolporius (Sw.) Desv. & 40 & 0.6 & 1.5 & 2.33 & 0.96 & 1.18 & 4.47 & 0.04 \\
\hline Lonchorcarpus cyanescens (Schum and Thonn.) Benth. & 60 & 2.4 & 4.0 & 3.49 & 3.86 & 3.14 & 10.49 & 0.07 \\
\hline Nauclea diderrechii (De Wild and Th. Dur.) Merrill & 20 & 0.2 & 1.0 & 1.16 & 0.32 & 0.79 & 2.27 & 0.05 \\
\hline Alchornea cordifolia (Schum. and Thonn.) Mull-Arg & 40 & 1.2 & 3.0 & 2.33 & 1.9 & 2.36 & 6.62 & 0.08 \\
\hline Oplimenus baumanni (Retz) P. Beauv. & 20 & 2.0 & 10.0 & 1.16 & 3.22 & 7.86 & 12.24 & 0.50 \\
\hline Combretum zenkeri Engl. and Diels & 20 & 1.0 & 2.5 & 1.16 & 1.61 & 1.97 & 4.74 & 0.13 \\
\hline Carpolobia lutea G.Don & 20 & 0.2 & 1.0 & 1.16 & 0.32 & 0.79 & 2.27 & 0.05 \\
\hline Desmodium ramosissimium G.Don & 20 & 0.4 & 1.0 & 1.16 & 0.64 & 0.79 & 3.76 & 0.05 \\
\hline Clerodendrum splendens G.Don. & 40 & 1.6 & 4.0 & 2.33 & 2.57 & 3.14 & 8.04 & 0.10 \\
\hline \multirow[t]{2}{*}{ Triumfetta eriophlebia Hook. f. } & 20 & 0.2 & 1.0 & 1.16 & 0.32 & 0.79 & 2.27 & 0.05 \\
\hline & 1720 & 62.2 & 127.2 & & & & 301.22 & \\
\hline
\end{tabular}

Table 3: Survey estimate of representative species around the Agrarian un-impacted control Amafor forest in Ngor-Akpala local government area of Imo state

\begin{tabular}{|c|c|c|c|c|c|}
\hline Species & $\mathrm{F}(\%)$ & Family & Habit & Common name & Remark \\
\hline Alchornea cordifolia (Schum. and Thonn.) Mull-Arg & 80 & Euphorbiaceae & Shrub & Christmas bush & ++++ \\
\hline Starchytarpheta jamaicensis Vahl. & 100 & Verbenaceae & Shrub & Brazilian tea & +++++ \\
\hline Cnestis ferruginea DC & 60 & Connaraceae & Shrub & & +++++ \\
\hline Heterotis rotundifolia $(\mathrm{Sm})$ Triana & 100 & Melastomataceae & Herb & Chickweed, rockrose & +++++ \\
\hline Barteria nigritana Hook F. & 60 & Passifloraceae & Shrub & & +++ \\
\hline Anthonotha macrophylla P. Beauv & 100 & Fabaceae-ceasal & Shrub & African rose wood & +++++ \\
\hline Carpolobia lutea G. Don & 40 & Polygalaceae & Shrub & Poor man's candle & ++ \\
\hline Combretum zenkeri Engl. and Diels & 80 & Combretaceae & Herb & & ++++ \\
\hline Pentachethra macrophylla P. Beauv & 40 & Fabaceae-ceasal & Tree & Oil bean & ++ \\
\hline Manniophyton fulvum Mull-Arg & 80 & Euphorbiaceae & Shrub & & ++++ \\
\hline Scleria naumanniana Boeck & 40 & Cyperaceae & Herb & Bush knife & ++ \\
\hline Landolphia dulcis Pichon (R.Br.) & 60 & Apocynaceae & Herb & & +++ \\
\hline Anthocleista djalonesis A. Chev & 80 & Loganiaceae & Tree & Cabbage tree & ++++ \\
\hline Tetracera allnifolia Willd & 40 & Dilleniaceae & Herb & Liana cord & ++ \\
\hline Maesobotrya dusenii (Pax) Hutch & 60 & Euphorbiaceae & Shrub & White bush cherry & +++ \\
\hline Harrungana madagascariensis Lam. ex Poir. & 100 & Guttiferae & Shrub & Dragon's blood & +++++ \\
\hline Funtumia elastica (Preuss) Stapf. & 40 & Apocynaceae & Shrub & & ++ \\
\hline Antidesma vogelianum Mull-Arg & 60 & Euphorbiaceae & Shrub & & +++ \\
\hline Vernonia ambigua Kotschy and Peyr & 80 & Asteraceae & Herb & Wild bitter leaf & ++++ \\
\hline
\end{tabular}


Table 4: Quantitative list of representative species around the Agrarian un-impacted control Amafor forest in Ngor-Akpala local government area of Imo state

\begin{tabular}{|c|c|c|c|c|c|c|c|c|}
\hline Species & $\mathrm{F}(\%)$ & $\mathrm{D}$ & A & RF (\%) & $\mathrm{RD}(\%)$ & RA (\%) & IVI & $\mathrm{A} / \mathrm{F}$ \\
\hline Alchornea cordifolia (Schum and Thonn) Mul-Arg & 80 & 3.0 & 3.8 & 6.15 & 5.12 & 4.42 & 15.69 & 0.05 \\
\hline Starchytarpheta jarmaicensis Vahl. & 100 & 1.6 & 1.6 & 7.69 & 2.73 & 1.86 & 12.20 & 0.02 \\
\hline Cnestis ferruginea DC & 60 & 4.0 & 6.7 & 4.62 & 6.83 & 7.79 & 19.24 & 0.11 \\
\hline Heterotis rotundifolia (Sm) Triana & 100 & 6.0 & 6.0 & 7.69 & 10.24 & 6.98 & 24.91 & 0.06 \\
\hline Barteria nigritana Hook F. & 60 & 3.6 & 6.0 & 4.62 & 6.14 & 6.98 & 17.74 & 0.10 \\
\hline Anthonotha macrophylla P. Beauv & 100 & 5.0 & 5.0 & 7.69 & 8.53 & 5.81 & 22.03 & 0.05 \\
\hline Carpolobia lutea G. Don & 40 & 2.0 & 5.0 & 3.08 & 3.41 & 5.81 & 12.30 & 0.13 \\
\hline Combretum zenkeri Engl. and Diels & 80 & 2.4 & 3.0 & 6.15 & 4.10 & 3.49 & 13.74 & 0.04 \\
\hline Pentachethra macrophylla P. Beauv & 40 & 1.0 & 2.5 & 3.08 & 1.71 & 2.91 & 7.70 & 0.06 \\
\hline Manniophyton fulvum Mull-Arg & 80 & 6.0 & 7.5 & 6.15 & 10.24 & 8.72 & 25.11 & 0.09 \\
\hline Scleria naumanniana Boeck & 40 & 1.0 & 2.5 & 3.08 & 1.71 & 2.91 & 7.70 & 0.06 \\
\hline Landolphia dulcis Pichon (R.Br.) & 60 & 3.0 & 5.0 & 4.62 & 5.12 & 5.81 & 15.55 & 0.08 \\
\hline Anthocleista djalonesis A. chev & 80 & 1.0 & 1.3 & 6.15 & 1.71 & 1.51 & 9.37 & 0.02 \\
\hline Tetracera alinifolia Willd & 40 & 1.6 & 4.0 & 3.08 & 2.73 & 4.65 & 10.46 & 0.10 \\
\hline Maesobotrya dusenii (Pax) Hutch & 60 & 2.0 & 3.3 & 4.62 & 3.41 & 3.84 & 11.87 & 0.06 \\
\hline Harrungana madagascariensis Lam ex Poir. & 100 & 5.0 & 5.0 & 7.69 & 8.53 & 5.81 & 22.03 & 0.05 \\
\hline Funtumia elastica (Preuss) Stapf & 40 & 3.2 & 8.0 & 3.08 & 5.46 & 9.30 & 17.84 & 0.20 \\
\hline Antidesma vogelianum Mull-Arg & 60 & 2.0 & 3.3 & 4.62 & 3.41 & 3.84 & 11.87 & 0.06 \\
\hline \multirow[t]{2}{*}{ Vernonia ambigua Ketschy and Peyr } & 80 & 5.2 & 6.5 & 6.15 & 11.09 & 7.56 & 24.80 & 0.02 \\
\hline & 1300 & 58.6 & 86.0 & & & & 302.15 & \\
\hline
\end{tabular}

regenerating species. The comparative study on the similarity of the impacted and unimpacted sites shows that both sites are dissimilar with an observed index value of 0.79 higher than the similarity index of 0.21 , though the area may not be significantly different in climatic regime and edaphic status.

\section{DISCUSSION}

One of the most important challenges for ecologist is gaining insight into the mechanisms that determine the distribution patterns of species in patchy habitats. Habitat alteration (including habitat loss, degradation and fragmentation) is now among the major risks of ecosystem degradation by human activities ${ }^{37}$. Man have altered ecosystem to varying degrees and the resultant array of natural, semi-natural and man made ecosystems within a landscape can be conceived as constituting both a readily measurable gradient of land use and a more complex gradient of anthropogenic effects. Thus various habitats can be regarded as spatially and temporally dynamic patches of vegetations with resultant decline in local and regional biota being subjected to diverse human interference ${ }^{38}$. Agrarian operation such as subsistence crop farming and carbon credit charcoal production is one of the key human induced elements in Amafor community in Imo State and this adversely determines the distribution of species and their habitat. But the most obvious and dramatic impacts are usually the direct disturbance on biodiversity leading to loss of flora and fauna complex ${ }^{39}$. The environmental impacts of agrarian operations have for several decades been envisaged and known to have a multiplier effect. Several studies have also shown a correlation between plant species population and diverse environmental changes.

This study shows that the flora and their environments provide a better understanding of the ecological consequences of disturbance as depicted in the result. The vegetation of the undisturbed forest was rich in trees and shrubby species than the impacted site. The low density and composition in tree and shrubs in the impacted site is attributed to the disturbances posed by agrarian practices as noted. This has been resulted to changes in vegetation structure in terms of abundance and species diversity. This corroborates ${ }^{40}$ who observed human activity as an important factor influencing plant species biodiversity. On such impacted site, spontaneous colonization is slow and the natural vegetation succession is often inefficient to ensure proper protection against other post impact environmental influences. This also corroborates the assertions of Whisenant et al. and Bradshaw ${ }^{41-43}$.

It has been lamented that over 11,300 ha of forest are been cleared annually in Nigeria forest for the establishment of monoculture plantation of indigenous and exotic trees ${ }^{44}$. It has also been established that the highest rate of forest modification have occurred in areas with heavy dependency on forest lands for subsistence and shifting agricultural practices largely found in developing countries ${ }^{45}$. These evidences present a 
significant and direct role of forest clearing in forest loss for farming. The greater abundance of lower vascular species among the families is an indication of a secondary vegetation structure, heterogeneous in nature as a result of the regeneration process with new species that were absent as adult. The high structural distribution of vegetation parameters in terms of life form in the undisturbed site was due to the relatively low level of disturbances. One of the fundamental and known characteristics of tropical rainforest or undisturbed natural vegetation is the great species richness or a large number of plant species in density and abundance per unit area ${ }^{3}$. However, there were still differences in the ranks of species frequency, diversity, density and abundance. Khater et al. ${ }^{46}$ compared levels of degradation and the resulting communities and found that less degraded sites favoured woody shrubs and perennial herbs while more degraded site favoured annual plants.

Community structure can be examined through the determination of various attributes of its component species and their relationship to each other. Such attributes among others may include plant species composition, abundance, density, frequency, diversity, basal cover, Importance Value Index (IVI) etc. The ecological characteristic of an area, its species diversity and regeneration status of species and habit influences the nature of any forest community ${ }^{47}$. The existence of plant species in forest community largely depends also on its regeneration establishment under varied environmental condition such as increased solar radiation incident on the forest floor. Consequently this could also influence the growth stages in seedling, sapling and young herbs, shrubs and trees of plant communities that maintain the population structure of any forest.

Species richness is one of the major criteria in recognizing the importance of an area for conservation ${ }^{48}$. Conservation is a fundamental component of sustainable ecosystem functioning which aims at recreating habitat for wildlife and flora. Studies on changes in species diversity and floristic composition of habitats have received appreciable attention ${ }^{49-51}$. Several factors are known to contribute to changes in species diversity and composition at any given time and place. The impact of grazing on the floristic and structural diversity in mountain Grasslands Island from Central Argentina has been studied ${ }^{52}$. Similar studies on the Mediterranean Island of Corsica reported loss of plant species richness and habitat connectivity due to agricultural changes in Finland ${ }^{53}$.
In the present research the heterogeneity of the vegetation of the impacted study area is being attributed to a retrogressive process such as the influence of farming and charcoal production operations and probably other forms of human activities, the regeneration and floristic succession of the study site. This has resulted to changes in vegetation structure in terms of abundance and species diversity. This corroborates the assertion by Cubizolle et al..$^{40}$ who observed human activity as an important agent influencing plant species biodiversity. There was a tremendous change in the floristic composition of the impacted study area with regard to differences in species time-lag adaptation associated with post-agrarian regeneration. This also corroborates the observation that vegetation in an anthropogenic influenced habitat is linked to ever increasing synanthropisation ${ }^{54}$. This was attributed to a number of direct or indirect human activities resulting to total changes in plant species biodiversity cover and loss of habitat connectivity $^{55,56}$.

The density, frequency, abundance and species diversity considered as indices of success in reforestation. Rajwar et al..$^{57}$ suggested that it is possible to re-establish a complete forest cover for the degraded deforested Amafor area by natural regeneration. The recorded indices are considered quite adequate to establish complete forest cover a very important step for biodiversity conservation. Ratio of abundance to frequency $(\mathrm{A} / \mathrm{F})$ indicated that the distribution of all the regenerated species in the impacted site was randomly distributed while the unimpacted site was contiguous in distribution. In a similar assertion contagious distribution pattern is the prevalent pattern in nature unlike random distribution found in every uninformed environment. Contagious distribution in natural vegetation has been reported by several workers ${ }^{58}$. From the research findings it is evident that the impacted forests of Amafor, are turning into diverse heterogeneous natural forest again.

\section{CONCLUSION}

The findings of present study provide a complete view of regeneration status in the study area which is rich in regenerating species that could result in the establishment of a diverse natural forest if protected to conserve the seedlings or saplings of the regenerating species. The results show that it is possible to bring the depleted area under complete forest cover through the protection of natural regeneration. 


\section{REFERENCES}

1. Whitmore, T.C., 1998. An Introduction to Tropical Rainforest. Oxford University Press Inc., New York, Pages: 282.

2. Myers, N.A., C. Russell, G. Mittermelert, A.B. Mittermelert, D.F. Gustavo and K. Jennifer, 2000. Biodiversity hot spots for conservation priorities. Nature, 24: 853-858.

3. Akinsanmi, F.A. and S.O. Akindele, 2002. Timber yield assessment in the natural forest area of oluwa forest reserve, Nigeria. Nigerian J. For., 32: 16-22.

4. El-Khouly, A.A.L., 2004. Effect of human activities on vegetation in Siwa Oasis. Proceedings of the International Conference on Water Resources and Arid Environment, Volume 112, August 3-6, 2004, Gaborone, Botswana, pp: 115-143.

5. Singh, S.P., 1998. Chronic disturbance, a principal cause of environmental degradation in developing countries. Environ. Conservation, 25: 1-2.

6. Wilcox, C.A., Y.M. Chun and Y.D. Choi, 2005. Redevelopment of black oak (Quercus velutina Lam.) savanna in an abandoned sand mine in Indiana dunes national lakeshore, USA. Am. Midland Nat., 154: 11-27.

7. Yuan, J.G., W. Fang, L. Fan, Y. Chen, D.Q. Wang and Z.Y. Yang, 2006. Soil formation and vegetation establishment on the cliff face of abandoned quarries in the early stages of natural colonization. Restoration Ecol., 14: 349-356.

8. Duan, W.J., H. Ren, S.L. Fu, J. Wang, L. Yang and J.P. Zhang, 2008. Natural recovery of different areas of a deserted quarry in South China. J. Environ. Sci., 20: 476-481.

9. Young, S. and L.N. Swiacki, 2006. Surveying the forest biodiversity of Evansburg State Park: Plant community classification and species diversity assessment. Int. J. Bot., 2: 293-299.

10. Prasad, P.R.C., C.S. Reddy and C.B.S. Dutt, 2007. Phytodiversity of tropical rainforest of North Andaman Islands, India. Res. J. For., 1: 27-39.

11. Reddy, C.S., S. Babar, A. Giriraj, K.N. Reddy and K.T. Rao, 2008. Structure and floristic composition of tree diversity in tropical dry deciduous forest of Eastern Ghats, Southern Andhra Pradesh, India. Asian J. Scient. Res., 1: 57-64.

12. Gentry, A.H., 1992. Tropical forest biodiversity: Distributional patterns and their conservational significance. Oikos, 63: 19-28.

13. Geldenhuys, C.J. and B. Murray, 1993. Floristic and structural composition of Hanglip forest in the South Pansberg. Northern Transvaal. South Afr. For. J., 165: 9-20.
14. Hopkin, B., 1968. Vegetation of the Olakemeji forest reserve. Nig. J. Ecol., 56: 97-115.

15. SAF., 1954. Forest Cover Types of North America. Society of American Foresters, Washington, DC., USA.

16. Edwin-Wosu, N.L., 2010. Eco-taxonomic baseline assessment of vegetation of pirigbene-obama-agip oil field further development project in Southern Ijaw local government area, Bayelsa State. Final Draft Report, NAOC/Sydney Gate-way (Nig) Limited, October 2010, pp: 3-38.

17. Edwin-Wosu, N.L., 2011. Eco-taxonomic postimpact assessment of vegetation of GOI lake oil spillage (EIA SHEWING)-Vegetation survey claim of Goi Community against Shell Petroleum Development Company (SPDC) in Gokana local Govt. Area. Government of India, pp: 3-19.

18. Edwin-Wosu, N.L., 2012. Environmental evaluation study of vegetation of the disused Imo River, Nkpoku, Obigbo North, Ebubu Pipeline (ROW) in Rivers State/ and Abia State. Wet Season Draft Report, MACPHED/SPDC, February, 2012, pp: $1-37$.

19. Edwin-Wosu, N.L., 2012. EIA baseline study of vegetation/Wildlife for the OBIAFU/OBRIKOMIndorama Eleme Fertilizer Company Limited (IEFCL) gas delivery pipeline project, August 2012. Environmental and Chemical Services Limited/Idorama Eleme Petrochemical Company Limited, pp: 1-90.

20. Kinako, P.D.S., 1988. Fundamental of Quantitative and Applied Plant Ecology. Belk Publishers, USA., pp: 26-45.

21. Hutchinson, J. and J.M. Dalziel, 1954. Flora of West Tropical Africa, Vol. 1. Par 1. Crown Agents for Oversea Government and Administrations, London, pp: 232-295.

22. Hutchinson, J. and J.M. Dalziel, 1958. Flora of West Tropical Africa, Vol. 1, Part 2. Crown Agents for Oversea Government and Administrations, London, pp: 298-756.

23. Hutchinson, J. and J.M. Dalziel, 1963. Flora of West Tropical Africa, Vol. 2. Crow Agents for Oversea Government and Administrations, London, pp: 1-473.

24. Hutchinson, J. and J.M. Dalziel, 1968. Flora of West Tropical Africa, Vol. 3, Part 1. Crown Agents for Oversea Government and Administrations, London, pp: 5-276.

25. Hutchinson, J. and J.M. Dalziel, 1972. Flora of West Tropical Africa, Vol. 3, Part 2. Crown Agents for Oversea Government and Administrations, London, pp: 277-512. 
26. Joyce, L. and D.P. Stanfield, 1974. The Flora of Nigeria: Sedges (Family Cyperaceae). Ibandan University Press, Ibadan, Nigeria, pp: 1-140.

27. Joyce, L., 1989. Flora of Nigeria Grasses. Ibadan University Press, Ibadan, Nigeria, pp: 28-294.

28. Austin, M.P. and P. Greg-Smith, 1968. The application of quantitative method to vegetation survey. J. Ecol., 56: 851-884.

29. Kershaw, K.A., 1973. Quantitative and Dynamic Plant Ecology. Edward Arnold Ltd., London, UK., Pages: 308.

30. Shukla, S.R and S.P. Chandel, 1980. Plant Ecology. 4th Edn., Chandel and Co., New Delhi, pp: 197.

31. Bonham, C.D., 1989. Frequency: Measurement of Terrestrial Vegetation. John Wiley and Sons, New York, USA., pp: 90-96.

32. Shannon, C.E. and W. Weiner, 1963. The Mathematical Theory of Communications. University of Illinois Press, Urbana, Illinois, pp: 1-10.

33. Pryor, L.D., 1981. Australian Endangered Species. Australian National Parks and Wildlife Service's Special Publication, Australia, pp: 139.

34. Misra, R., 1980. Ecology Workbook. 1st Edn., Oxford and IBH Publ. O., New Delhi, India.

35. Curtis, J.T. and G. Cottam, 1956. Plant Ecology Work Book: Laboratory Field Reference Manual. Burgess Publishing Co., Minnesota, pp: 193.

36. Sorensen, T.A., 1948. A method of establishing groups of equal amplitude in plant sociology based on similarity of species content. K. Danake Videnk Biol. Skr., 5: 1-34.

37. Whitfield, D.P., D.R.A. McLeod, A.H. Fielding, R.A. Broad, R.J. Evans and P.F. Haworth, 2007. The effects of forestry on golden eagles on the island of Mull, western Scotland. Western Scotland J. Applied Ecol., 38: 1208-1220.

38. Kitazawa, T. and M. Othsawa, 2002. Pattern of species diversity in rural herbaceous community under different management regime, China Central Japan. Biol. Conservation, 104: 239-249.

39. John, R.H., 2009. Ecological restoration of quarry site: A systematic review of literature draft. Barnaby Letheren, School of the Environment and Natural Resources, Bangor University.

40. Cubizolle, H., A. Tourman, J. Argant, J. Porteret, C. Oberlin and K. Serieyssol, 2003. Origins of European biodiversity: Palaeo-geographic signification of peat inception during the Holocene in the granitic Eastern Massif Central (France). Landscape Ecol., 7: 211-227.
41. Whisenant, S.G., T.L. Thurow and S.J. Maranz, 1995. Initiating autogenic restoration on shallow semiarid sites. Restoration Ecol., 3: 61-67.

42. Bradshaw, A.D., 1993. Understanding the Fundamentals of Succession. Scientific Publications, USA., pp: 1-20.

43. Bradshaw, A., 1997. Restoration of mined lands-using natural processes. Ecol. Eng., 8: 255-269.

44. Ola-Adams, B.A., 1996. Conservation and management of biodiversity: Biosphere Reserves for Biodiversity Conservation and sustainable Development in Anglophone African (BRAAF). Assess. Monitoring Techniques Nigeria, 32: 41-46.

45. Allen, J.C. and D.F. Barnes, 1985. The causes of deforestation in developing countries. Ann. Assoc. Am. Geography, 75: 163-184.

46. Khater, C., A. Martin and J. Maillet, 2003. Spontaneous vegetation dynamics and restoration prospects for limestone quarries in Lebanon. Applied Vegetation Sci., 6: 199-204.

47. Alamgir, M. and M. Al-Amin, 2007. Regeneration status in a proposed biodiversity conservation area of Bangladesh. Proc. Pak. Acad. Sci., 44: 165-172.

48. Khumbongmayum, A.D., M.L. Khan and R.S. Tripathi, 2005. Sacred groves of Manipur, northeast India: Biodiversity value, status and strategies for their conservation. Biodiversity Conservation, 14: 1541-1582.

49. Duke, N.C., 1992. Mangrove Floristic and Biogeography: Tropical Mangrove Ecosystem. In: Coastal and Estuarine Series 42, Robertson, A. and D.M. Alongi (Eds.). American Geophysical Union, Washington, DC., pp: 63-100.

50. Field, C.D., 1995. Journey Amongst Mangroves. International Society for Mangrove Ecosystem, Okinawa, Japan, pp: 144.

51. Edwin-Wosu, N.L. and E.A.B. Edu, 2013. Eco-taxonomic assessment of plant species regeneration status in a post-remediated crude oil impacted site in parts of Ibibio-I-Oil field in Ikot-Ada Udo, Ikot-Abasi Local Government Area of Akwa Ibom State, Nigeria. Asian J. Plant Sci. Res., 3: 14-23.

52. Nai-Bregaglio, M., E. Pucheta and M. Cabido, 2002. Grazing effects on the floristic and structural diversity in mountain grasslands from Central Argentina. Rev. Chil. Hist. Nt., 75: 613-623.

53. Said, S., 2002. Floristic and life form diversity in post-pasture successions on a Mediterranean island (Corsica). Plant Ecol., 162: 67-76. 
54. Ahmad, S.S., T. Ahmad and K.F. Akbar, 2004. Baseline study of roadside vegetation of lahoreislamabad motorway $\left(\mathrm{M}^{-2}\right)$ and its fertility status. J. Applied Sci., 4: 266-270.

55. Luoto, M., S. Rekolainen, J. Aakkula and J. Pykala, 2003. Loss of plant species richness and habitat connectivity in grasslands associated with agricultural change in Finland. AMBIO: J. Hum. Environ., 32: 447-452.

56. Paciencia, M.L.B. and J. Prado, 2005. Effects of forest fragmentation on pteridophyte diversity in a tropical rain forest in Brazil. Plant Ecol., 180: 87-104.
57. Rajwar, G.S., M. Dhaulakhandi and P. Kumar, 1999. Regeneration status of an Oak forest of Garhwal Himalaya. Indian For., 125: 623-630.

58. Verma, R.K., D.K. Shadangi and N.G. Totey, 1999. Species diversity under plantation raised on a degraded land. Malaysian For., 62: 95-106. 